Providence College

DigitalCommons@Providence

Fall 2007

\title{
"Creatures of Mimic and Imitation": The Liberty Tree, Black Elections, and the Politicization of African Ceremonial Space in Revolutionary Newport, Rhode Island
}

\author{
Edward E. Andrews \\ Providence College
}

Follow this and additional works at: https://digitalcommons.providence.edu/history_fac

Part of the United States History Commons

Andrews, Edward E., "'Creatures of Mimic and Imitation": The Liberty Tree, Black Elections, and the Politicization of African Ceremonial Space in Revolutionary Newport, Rhode Island" (2007). History \& Classics Faculty Publications. 2.

https://digitalcommons.providence.edu/history_fac/2

This Article is brought to you for free and open access by the History \& Classics at DigitalCommons@Providence. It has been accepted for inclusion in History \& Classics Faculty Publications by an authorized administrator of DigitalCommons@Providence. For more information, please contact dps@providence.edu. 


\title{
“Creatures of Mimic and Imitation": The Liberty Tree, Black Elections, and the Politicization of African Ceremonial Space in Revolutionary Newport, Rhode Island
}

\author{
Radical History Review
}

\section{Edward E. Andrews, Ph.D. \\ Department of History \\ Providence College}

\begin{abstract}
"We of this age can hardly comprehend the significance attached to the planting of a tree which was to be consecrated, every fibre of it, - root, trunk, limb, branch, and twig - as the symbol of national liberty. The words "American Liberty" were hateful words to the Tories; and they vented their spleen upon this symbol of deliverance from the British yoke."
\end{abstract}

- George G. Channing, 1868

"The tree may stand in the street but its roots are in the house."

- African Proverb

During the Stamp Act crisis of the mid-1760's, colonial Americans rallied around Liberty trees and Liberty poles as symbols of patriotic resistance to British tyranny. The Stamp Act declared that all paper documents, including marriage licenses, business transactions, wills, and even playing cards, had to be stamped with an official seal that appointed Stamp Masters would sell and distribute. It was designed to raise revenue after a costly Seven Years' War against the French, but it instead raised the ire of many Americans and propelled a group of patriots, known as the Sons of Liberty, into the international spotlight. ${ }^{1}$ Like many other seaports during the Revolutionary era, Newport, Rhode Island experienced a series of Stamp Act riots, rejoiced when news of the hated Act's repeal arrived in the spring of 1766, and commemorated the repeal by dedicating a special Liberty Tree as a symbol of American resistance to British oppression. This "Large Button Wood Tree" dominated the corner of Farewell and Thames streets, a triangular piece of property owned by a man named William Read. ${ }^{2}$ Read, himself a Son of Liberty, deeded the property to a few other Sons in April of 1766 so that the tree could forever "stand as a Monument of the Spirited and Noble Opposition made to the Stamp Act."” This 
space would be used by Newport's Sons of Liberty for later commemorations, ceremonies, and patriotic celebrations. Newport's Liberty Tree thus became a sacred symbol in the struggle against what many colonial Americans believed to be British tyranny, oppression, and enslavement. ${ }^{4}$

Interestingly, Newport's Sons of Liberty was not the first group to sacralize the space around the Liberty Tree. ${ }^{5}$ The seaport's African population was already having annual celebrations, commonly called the "black elections," at that very space for well over a decade before the Sons of Liberty appropriated the site for their own rhetorical purposes. Occurring throughout New England in the eighteenth and early nineteenth centuries, these black elections served as important ceremonies where Africans would celebrate, share stories, engage in feats of strength, elect a black "king" or "governor," and process through the streets when the day was done. White observers, however, mocked these African celebrations as pathetic attempts to impersonate Anglo-American political culture. One early $19^{\text {th }}$ century commentator described Africans as "creatures of mimic and imitation" who held the elections only because they observed "the pride which their masters took in their charter government, and the ambition with which they strove and contended with one another for honor, office and preferment." ${ }^{6}$ Though later histories would replicate this interpretation, more recent studies have instead emphasized the creative and fundamentally African, rather than mimetic, nature of these election rituals. Indeed, the roots of black culture in Newport were clearly in Africa. ${ }^{7}$

Indeed, the symbolic importance ascribed to the Liberty Tree had previous transatlantic origins that gave this natural feature a highly charged significance for both African and AngloAmericans living in Newport. Thus, employing a definition of culture that includes the use of ceremonial space by different groups reveals an interesting inversion: though Newport's black 
population may have been influenced by white political culture, the Sons of Liberty themselves became "creatures of mimic and imitation" when they appropriated an African ceremonial space as their own.

\section{An African Space}

Like other colonial American seaports, Newport possessed a large population of people of African descent. The town's rum industry, proximity to labor-hungry farms on the other side of the Narragansett, and dependence upon the African slave trade ensured that Newport witnessed a steady influx of slaves from both the West Indies and Africa. ${ }^{8}$ The town had over 1200 blacks by the middle of the eighteenth century, constituting nearly $20 \%$ of the total population and making Newport the second blackest city on the American mainland. ${ }^{9}$ African slaves who came directly to Newport were usually shipped from the Gold Coast and consisted of Mandingo, Mende, Ibo, Ashanti, and Fante peoples, though many may have originated from further inland. ${ }^{10}$ Though it is impossible to determine exactly how many Africans came straight from the other side of the Atlantic to Newport, the African cultural influence can be found in the grave markings at the town's Common Burial Ground. With names like Duchess Quamino, Salmar Nubia, Occramar Mirycoo, and even the quite obvious Cape Coast James, these tombstones demonstrate the persistence of West African naming patterns and culture in New England. ${ }^{11}$

Newport's black population may have originated from different regions and groups, but the town's Africans could draw on a common cultural vocabulary that gave trees a sacred, and even cosmic, significance. Traditional West African religions were often pantheistic, where every person, animal, or tree were all living, they all had their own souls and wills, and they were 
all therefore spiritually connected. ${ }^{12}$ Contrary to many European assumptions about West African religion, Africans did not worship trees themselves as gods or deities. Instead, trees were sacred spaces for a number of reasons: they were a common motif in African creation stories, some Africans believed them to be the dwelling place of spirits, and their seed, growth, and death stood as a natural metaphor to the rhythms of the human lifecycle.

Some African groups believed that the Tahu tree, for example, was the "first tree and origin of all later vegetative life." Their creation stories tell of how a chameleon that lived in the Tahu tree heard a noise within it. The curious chameleon listened closely and began tapping back on the bark of the tree. Suddenly, a hole opened up in the bark and a wave of water gushed out of the tree, carrying the first man with it. Anthropologists have found similar creation stories among the indigenous peoples of the Caribbean. ${ }^{13}$ Linked with these creation stories, the tree also operated as a symbol for fertility, regeneration, and healing. Some West African groups believed that the nuts from a palm tree "ensured conception to any barren woman" and that making offerings to the spirits within a sacred tree could help cure sickness. ${ }^{14}$ Just as trees could act as symbols and living metaphors of regeneration and life, they were also associated with death. Some Africans believed that sacred trees and groves could serve as the resting place for dead souls. The Akamba, for example, believed that the wild fig tree was a "favorite" dwelling place for the spirits. In southern Nigeria many villages in the Indem possessed a sacred tree "into which the souls of the villagers are believed to pass at death." These sacred trees were protected by law and were not allowed to be cut down. ${ }^{15}$

Other West Africans used sacred groves as spaces for important initiation rites and communal gatherings. The Bambara of Mali brought young boys out into a sacred grove and made them painstakingly construct objects which they would hang from the center tree. 
According to Bambara tradition, "the tree... is the World Tree joining earth to sky; it is the source of regeneration, like the mythic tree in the beginning of time. From it the novices are born anew." ${ }^{16}$ Just as trees had their own animating and regenerative spirit, they were also important spaces for communal gatherings and worship. Many African societies had a sacred grove, and though Africans differed in the power and cultural meaning that they ascribed to these groves, the use of trees as a sacred space is quite common. Large silk-cotton, iroko, and baobob trees all had a sacred significance in different regions of Africa (though not every tree was sacred). ${ }^{17}$ One eighteenth century African prince remembered the many village gatherings under the same tree that produced important food and even a "very delicious" wine that the villagers harvested every year. He also recalled gathering for worship under the branches of a large and sacrosanct palm tree: "Our place of meeting is under a large palm tree; we divide ourselves into many congregations; as it is impossible for the same tree to cover the inhabitants of the whole city, though they are extremely large, high, and majestic." ${ }^{18}$ The prince thus revered the tree as both a natural benefit and a site of cultural meeting and exchange. In short, Africans perceived in different, but significant, lights: as the originator of human life, a source of healing and regeneration, a sacred space where dead souls resided, a natural fixture upon which they depended, and as a communal space for celebration and worship.

Africans carried these ideas about the sacred and cosmic meaning of trees across the Atlantic. ${ }^{19}$ According to local tradition in Newport, the black community began holding African celebrations near the site of the Liberty Tree by 1755 . Though it is still unclear exactly who made the decision to hold these "black elections" there in the first place, black leaders chose that site based on cultural conviction, not convenience. As indicated in the 1777 town map by Charles Blaskowitz (see image), the Liberty Tree was on the fringes of the town center. Few 
blacks lived in large numbers in any one house, as Newport's black slaves were scattered residentially among the various merchants and artisans of the town. ${ }^{20}$ Thus, the Liberty Tree was not necessarily close or convenient for Newport's black community, as most had to travel some distance to get there. Perhaps the tree's location away from the town center, and therefore the critical eye of white authority, was one of the reasons why the black community chose this spot. The tree was also quite large by all accounts. The owner of the property, a man named William Read, described the tree in 1766 as a "Large Button Wood Tree," thus suggesting its age. A view of the town of Newport from the 1740's (see image) also indicates that the tree rivaled even the largest buildings around it. ${ }^{21}$ Finally, the association of African sacred trees with dead souls gives a final clue as to its choice as a sacrosanct space. This plot of land was only a few yards from the Common Burial Ground, where the black population had its own burial space. In order to travel from town center to the cemetery, one had to pass by the tree, thus mirroring some West African traditions that sacred trees were gateways between living souls and dead ones. When Henry Bull complained that Newport's Africans "took great pride in making their funerals as pompous as possible," he was bearing witness to the continuation of West African funerary rituals, where processions would wind their ways through villages with great celebration and fanfare. The Liberty Tree thus acted as an African intermediary between the space of the living (the town center) and the space of the dead (the town cemetery). ${ }^{22}$

The black population had thus begun to make the Liberty Tree a sanctimonious space by beginning their black elections there in 1755 , which was around the same time that the population of Africans living in Newport was at its zenith. The elections were not unique to Newport, as they occurred throughout the Atlantic world and New England, though they took on different manifestations depending on the historical and cultural contexts. There are few 
contemporary descriptions of these elections, but several $19^{\text {th }}$ century reminiscences and memoirs discuss them in great detail. ${ }^{23}$ Henry Bull's memoir, published in the Rhode Island Republican in 1837, described Newport's black elections as an annual celebration, usually occurring in June, when the black community would congregate, celebrate, and elect a governor who would serve as leader of their people for a year. The space appointed for this ceremony was, of course, under "a large spreading tree which stood in the place where the Liberty Tree now stands at the head of Thames street." The day began with a procession to the Tree, and there is much evidence to indicate that slaves may have borrowed their masters' clothing for this highly important event. The voting (there were some property qualifications) was done by paper ballot, and a "grand jollification" erupted when the ballots were counted and the winner of the election was declared. The celebration then began, and it included wrestling, singing, dancing, and other activities. At the end of the celebration, another procession was formed, and this wound its way through Newport's streets to the home of the new black governor, where his supporters and political allies were treated with food and burnt rum.

In the ensuing year, the governor's responsibilities included mediating disputes, maintaining social order, and punishing transgressions. Punishment was quite controversial because it would sometimes come in the form of striking a slave on the back with a bastinado, or a wooden board that originated in the West Indies and was often used by overseers or other white authorities. Bull recalled that "the punishment was quite severe, and what made it the more effectual was, that it was the judgment of their peers, people of their own rank and color had condemned them, and not their masters by an arbitrary mandate." Furthermore, if these ceremonies may have served as opportunities to critique the system of American slavery or embrace a nascent political identity, there is no evidence that these celebrations ever turned into 
riots or rebellions. ${ }^{24}$ White observers might have feared the worst from a large gathering of hundreds of slaves. Yet no one, not even William Read, publicly complained about these events. In fact, these peaceful gatherings probably contrasted greatly with the rancorous and disorderly general elections that white Rhode Islanders held in May. ${ }^{25}$

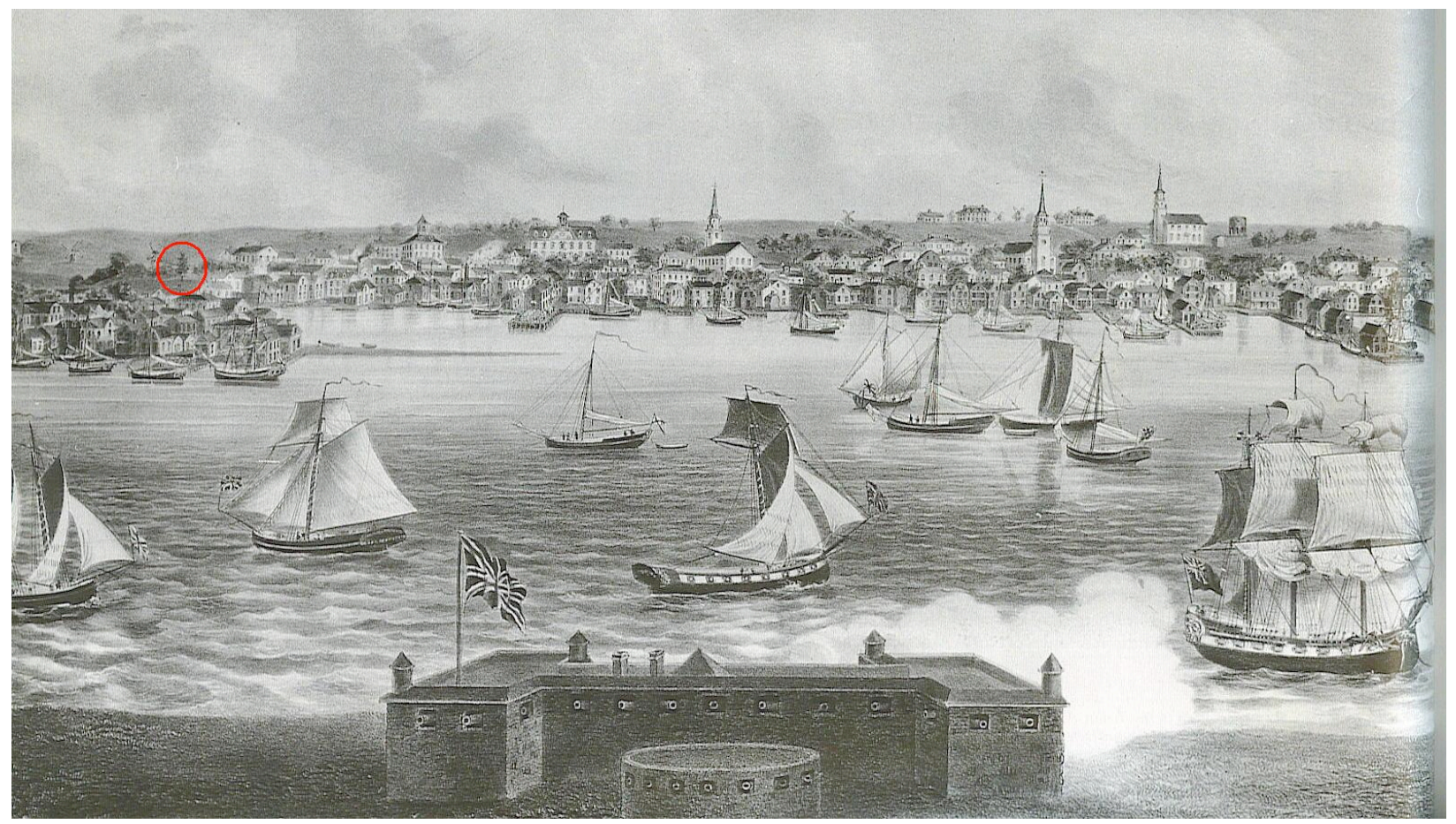

This untitled view of Newport from the 1740's clearly shows the astonishing size of the old buttonwood Liberty Tree. A few blocks from the town center, this was the space where African slaves celebrated their annual black elections and where the Sons of Liberty celebrated the repeal of the Stamp Act. This image is taken from a late nineteenth century lithograph printing by James Newell. The original painting is an over mantle piece held in a private collection. Courtesy Newport Historical Society, Newport, Rhode Island.

Though many white contemporaries, and even later historians, would agree with Henry Bull that Newport's blacks were simply mimicking white political election culture, the black elections were highly Africanized events. First and foremost, the decision to choose the Liberty Tree as this ceremonial space made sense, considering the sacred importance that many West Africans attached to large trees. African music was the tune of the day, as Bull recalled that "every voice upon the highest key, in all the various languages of Africa, mixed with the broken and ludicrous English, filled the air, accompanied with the music of the fiddle, tambourine, the 
banjo, drum \&c." ${ }^{26}$ There was also a high frequency of the electors choosing a native-born African or even an African prince. Indeed, William Piersen found that these ceremonies were essentially "festivals honoring Afro-American royalty," as one-third of the elected leaders on record were of African royalty or were native-born Africans. ${ }^{27}$ Other historians have suggested that the black elections resembled a combination of Ashanti festival. The Adae ceremony, in particular, was a ritual procession where African royalty dressed in its finest and was escorted through the city or village by a large procession of people, mirrored many of the winding processions that white observers witnessed in New England. ${ }^{28}$ The black elections also mirrored the Ashanti Odwira festival, a rite of purification that occurred annually around the summer solstice. This Ashanti association with purification, rejuvenation, and the cyclical changes of a new season also help explain why the Liberty Tree, long associated with these themes, became a logical spot for these African ceremonies. ${ }^{29}$

It is most likely that the wartime disruptions of the American Revolution put an end to the black elections around the time of British occupation in 1776. Though the elections would reappear on the other side of the Narragansett Bay after the Revolution, there is no evidence that Newport's black community continued to celebrate them in the early Republic. ${ }^{30}$ The cessation of the black elections should be seen as part of a larger pattern of cultural and social disruption that the Revolution produced. As George Champlin Mason recalled, "the gayeties of Newport were greatly interfered with by the War of the Revolution, which put a stop to all entertainments." Indeed, even after the British ended their occupation of Rhode Island, much of Newport's community "could scarcely provide for the wants of life, much less think of festivities." ${ }^{31}$ It is likely that the black elections kept occurring every June up to the period of 
British occupation. By that time, however, another group began appropriating this sacred space for their own struggle against enslavement and tyranny.

\section{Converting African Space into the Liberty Tree}

Like Newport's African slaves, the town's Anglo-Americans also drew on a transatlantic heritage that conferred sacred status upon some trees. The most obvious example of this was in the second and third chapters of the Book of Genesis, when the fruit of the Tree of Knowledge of Good and Evil was eaten by Eve in the Garden of Eden. For Christians, the wooden cross on which Christ was crucified served as a kind of intermediary between the material world and the world of the supernatural. For Christ, the cross was also a symbol of his resurrection and rejuvenation. Trees were sacred symbols in antiquity, as well. James George Frazer discovered that "the sacred fig-tree of Romulus was worshipped down to the days of the [Roman] empire, and the withering of its trunk was enough to spread consternation through the city." ${ }^{32}$ The Dutch and Germans also had traditions of associating trees with celebration and liberty, and some historians have suggested that the ascension of William III to the English throne reinforced, if not introduced, these ideas in the British Isles. ${ }^{33}$ The English, of course, had the famous peasant tradition of May-Day. One eighteenth century commentator recalled that, around Cornwall, "they make excursions, on May eve, into the country, cut down a tall elm, bring it into town with rejoicings, and having fitted a straight taper pole to the end of it, and painted it, erect it in the most publick part, and upon holidays and festivals dress it with garlands of flowers, or ensigns and streamers. ${ }^{34}$ In this context English trees were, like African trees, connected with the regenerative qualities of spring and the cyclical seasons of nature. ${ }^{35}$ 
As the English migrated to the Americas, trees became symbols of English liberty on both sides of the Atlantic. A Tulip poplar marked the spot where, in 1652, Indians opened up the Chesapeake for settlement. Another tree marked where William Penn made a peace treaty with Pennsylvania Indians in 1683. When British officials sought to revoke Connecticut's charter in 1687, locals hid the document either in or under what became known as the "Charter Oak." The practice of hanging effigies from trees when English liberties were threatened also became more common in the eighteenth century. After the Excise Law was passed in 1763, residents of Devonshire, England hung an effigy of Lord Bute (whom they blamed for the tax) from an apple tree. The poem which accompanied the effigy read: "And now he hangs upon a tree...An emblem of our liberty." ${ }^{37}$ The tree could also symbolize economic liberty, especially in New England. The mighty forests of that region provided the British with masts while the ships in Newport's harbor constantly reminded colonial Americans of their dependence upon trees for their economic livelihood. In fact, when Rhode Island's Esek Hopkins steered his slave ship, Sally, onto the West African coast in 1764, he noted purchasing some African slaves under a Palavor tree. The tree thus became a site where Hopkins's economic liberty and the bondage of African slaves converged. Interestingly, that ship experienced a famous, but failed, slave insurrection on its way back to the colonies. In English tradition, then, trees stood as symbols of fertility, strength, but they also served as sites of communal gathering, solidarity, and expressions of economic and political liberty. ${ }^{38}$

In North America, the tree took on another metaphorical meaning: that of transplantation. Anglo-Americans used natural metaphors to describe how English liberty had taken firm root in the American soil. At the dedication of the Liberty Tree in Providence in 1768, Silas Downer gave a powerful oration on the strength of English liberty in the new world. He exclaimed, 
"May all our councils and deliberations under it's venerable branches be guided by wisdom, and directed to the support and maintenance of that liberty, which our renowned forefathers sought out and found under trees and in the wilderness. ${ }^{39}$ Far from turning Europeans into savages, the new world was a land full of rich soil, where liberty could take firm root away from the decadence and decay of the Old World. ${ }^{40}$

If trees were symbols of English liberty and served as key icons in what Catherine Albanese has called the "sacred theater of public demonstration," their importance was only augmented when, due to the massive debt compiled during the Seven Years' War, the British government increased taxes on colonists and enforced previous measures that had long been ignored. ${ }^{41}$ In the initial resistance to Parliamentary measures, Boston led the way. That town's Liberty Tree (a great Elm located on the corner of present-day Essex and Washington Streets) served as both a rallying point and an emblem of resistance to British tyranny. The Tree was the site where the Sons of Liberty gathered and where an effigy of Andrew Oliver, the Stamp Master, was "found hanging...in the most Publick part of town." Boston's patriots also forced Oliver to resign at that very site on a cold and rainy day in December. ${ }^{42}$ Though Boston took the initiative, other towns along the eastern seaboard soon gathered around Liberty Trees or erected Liberty Poles when a suitable tree was not to be found. Newport, New York, Philadelphia, and Charleston all had these symbols, but so did the smaller towns of Cambridge, Dedham, and even Greenland, New Hampshire. The more fervent residents of Plymouth, Massachusetts tried to up the ante of political iconography by transporting the famous Plymouth Rock from the shore to the town center. Once there, they hoped to place a massive Liberty Pole on top of it. The gesture would have embodied both the religious and political freedom that the region claimed to embrace. Unfortunately, the eager and ardent patriots split the legendary rock in two in the 
process of attempting to move it. ${ }^{43}$ Even a popular song used by the Sons of Liberty reinforced the metaphor of a tree in the protection of English liberties:

Hearts of oak are we still, for we're sons of those men, Who are always ready, steady, boys, steady, To fight for their FREEDOM again and again. ${ }^{44}$

Unlike Boston's Liberty Tree, there is no evidence that Newport's Tree was an active participant in the Stamp Act Riots that erupted in late August of 1765. Newport's riots began with the hanging of effigies of the proposed Stamp Master (Augustus Johnston) and two men who publicly defended the right of Parliament to tax the colonists (Dr. Thomas Moffat and Martin Howard, Jr.). ${ }^{45}$ The effigies were burned, people went home, and the mock funeral appeared to end peacefully. But the leaders of the Stamp Act resistance (most notably William Ellery, Robert Crook, and Samuel Vernon) allegedly instigated the mob into further action later on that night by offering the rioters "strong Drink in plenty with Cheshire Cheese." The “enraged and desperate mob," many of whom may well have included slaves, free blacks, and poor sailors, then went to the homes of Moffat and Howard and completely destroyed their books, furniture, walls, dining ware, and even wine cellars. The mob searched for Howard, Moffat, the Stamp Master, and other known Stamp Act sympathizers, but most of them had wisely sought sanctuary aboard a British man-of-war that was anchored in the harbor. In the early morning hours the mob returned to Howard's house and, finding nothing left to destroy, "concluded their triumphal victory by cutting down the locust trees" which were planted in front of his home. Once cut, the mob "Bro't them and Stuck them up in two Great guns which have been fix"d at the Bottom of the parade some Years as Posts." In the context of this discussion of the symbolic importance attached to trees, this closing act of the mob was not a random or drunken act: it was quite appropriate and symbolically meaningful. ${ }^{46}$ 
The appropriation of Newport's Liberty Tree, which had been an African ceremonial space for about a decade, actually took place well after these Stamp Act riots had died down. Indeed, the Liberty Tree became a more prominent symbol as news of the hated Act's repeal in the spring of 1766 spread through sailors, oral transmission, and the Newport Mercury (the local newspaper). The actual process of conversion took place through the annual celebratory rituals, the lighting of candles, the blasting of cannon, and the gathering of the townspeople. When the repeal was officially announced, the "Bells of the Town were immediately rung, the Shipping in the Harbour displayed their Colours, Liberty Tree was also adorned with the same," and the Sons of Liberty appeared victorious against a conspiratorial Parliament. ${ }^{47}$ The sons celebrated the repeal of the Stamp Act at the tree every March 18. Canons were discharged, church bells rang, and there were celebratory orations and dinners hosted by the Sons of Liberty. As the Revolutionary crisis deepened by 1775 , however, celebrations became less common. One local minister recorded in his diary that Newporters stopped celebrating at the Liberty Tree, or anywhere else, because they were finding that "the repeal was not done on generous fraternal principles, as America at first conceived." He described the cheerless scene, recalling that "A few Boys jingled the Bells a little, but were soon stopt." ${ }^{, 48}$

Unfortunately, there is no direct evidence that indicates why the Sons of Liberty would appropriate the same space that Africans used for their annual black elections. One central criterion for the Liberty Tree was that it had to be old, and that also meant large. An eighteenth century Frenchman, who also revered liberty trees, pronounced that "the tree destined to become the emblem of liberty...must be chosen from those with long lives and, if it cannot be everlasting, at least it should be chosen from among those trees whose life lasts several centuries. ${ }^{49}$ The painting of Newport's harbor from the 1740's (see image) shows that this 
buttonwood tree dwarfed other trees and even structures that surrounded it. Another possible reason why the Sons chose this particular tree was its proximity to the town burial ground. Patriotic resistance to "tyranny" often involved the use of death and funerary metaphors. For example, the hanging and burning of effigies was quite common, and patriots even staged mock funerals for Liberty itself. But just as Liberty was about to be interred in these allegorical dramas, it would courageously reawaken from its slumbers and once again lead the people. ${ }^{50}$ In this case, the town's burial ground might have served as a dramatic backdrop to the effigies and mock funerals that the Sons of Liberty expected to perform around the Liberty Tree. The only problem with the tree's location was the same feature that made it so appealing to Newport's black community: it was a few blocks from the town center, and therefore away from the space where the political theater of the Stamp Act riots had played out only a few months before.

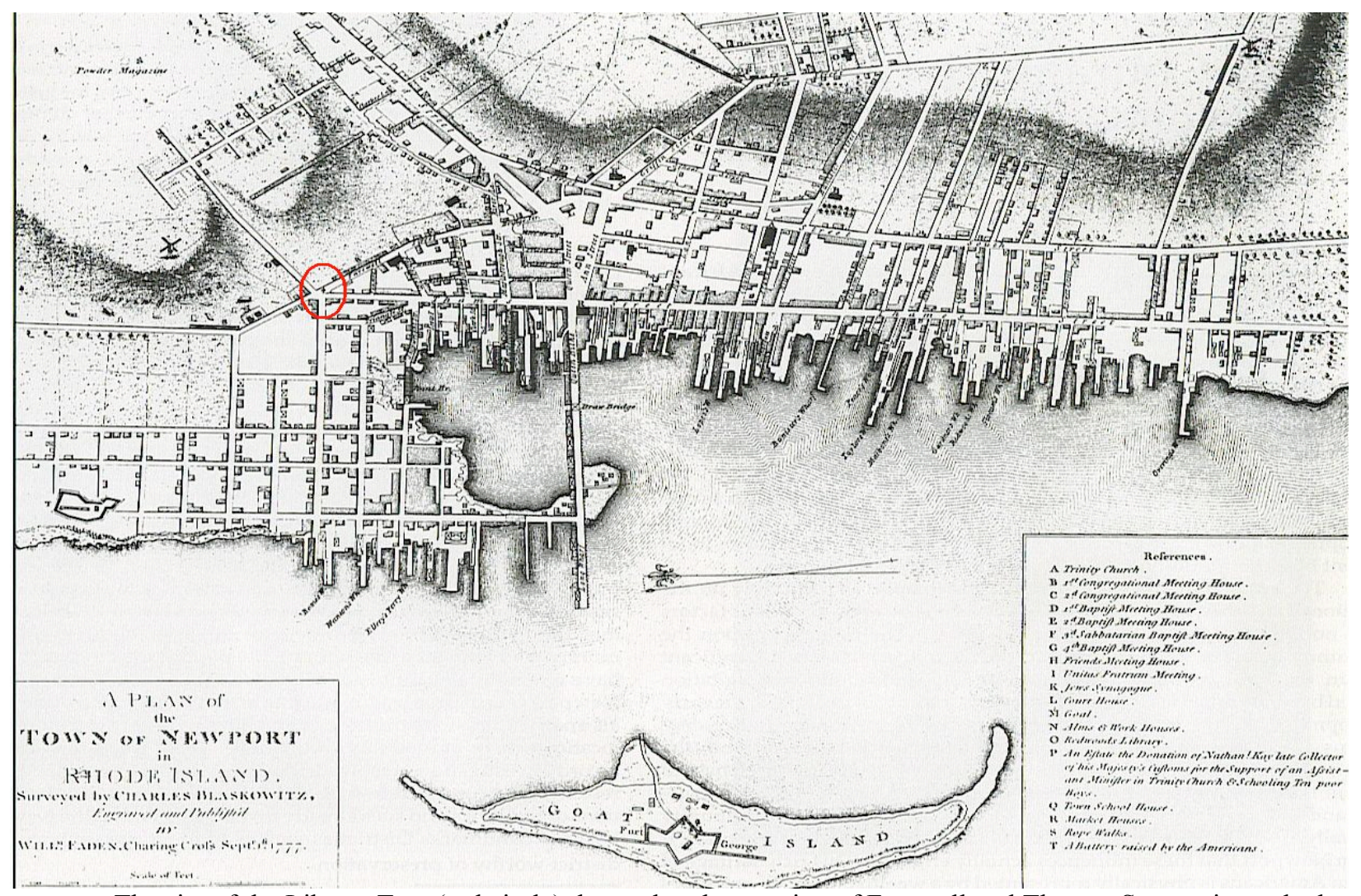

The site of the Liberty Tree (red circle), located at the meeting of Farewell and Thames Streets, is marked with a small tree (the original tree might have already been cut down by British forces by then). The town center 
extended from the wharf all the way up to the triangular "square" along Queen Street. From Charles Blaskowitz, $A$ Plan of the Town of Newport, Rhode Island, 1777. Courtesy Newport Historical Society, Newport, Rhode Island.

In spite of its peripheral location, the tree at the meeting of Thames and Farewell streets possessed one final advantage: the property upon which it stood was owned by William Read, a wealthy merchant, local politician, and prominent member of Newport's Sons of Liberty. Read deeded the land to his friends and fellow Sons, William Ellery, Robert Crook, John Collins, and Samuel Fowler (but not without first accepting the small price of five shillings) when news of the repeal of the Stamp Act hit Newport in April of 1766. Most of them were attorneys or merchants, and Ellery and Crook were key leaders in the earlier Stamp Act riots. Ellery later became one of the signers of the Declaration of Independence. Read's deed was no ordinary land transaction, however, as it quickly became a public discourse on the centrality of this Tree in the protection of American liberties. Read even had the deed published in the Newport Mercury so the town's citizens could witness the patriotic spirit that moved him to donate his property to the cause of liberty. In both his deed and public declaration, Read explained that the Liberty Tree would be "Emblematical of Publick Liberty and of her taking deep root in English America, of her Strength and Spreading Protection...refreshing her Sons in all their struggles against the Attempts of Tyranny and Oppression." Similar to African cultural attitudes towards trees, Read emphasized the regenerative quality of this particular tree. Invoking the Tree of Knowledge of Good and Evil in the Book of Genesis, Read also claimed that the tree would act as a judge of patriotism and tyranny in these trying times. Read forecasted that "the said Tree of Liberty is destined and set apart for exposing to the Publick Ignominy and Reproach all offenders against the Liberties of their Country and Abettors and Approvers of such as would enslave her." 51 
Historians have eloquently examined this "central paradox" in American history: that liberty loving patriots could speak of their fear of British enslavement while they owned slaves. ${ }^{52}$ Indeed, the juxtaposition of slavery and liberty had a long historical relationship, and Liberty Trees served as sites where that relationship could be exposed and exploited. Residents of Dedham, Massachusetts erected a Liberty Pole with a bust of William Pitt, whom they thought saved them from oppression by supporting the repeal of the Stamp Act, at its apex. The monument was dedicated to Pitt "and other patriots who saved America from impending slavery. ${ }^{, 53}$ When Silas Downer delivered his fiery oration at the dedication of Providence's Liberty Tree in 1768 , he referred to slavery nearly half a dozen times. At the conclusion of his speech, he exclaimed, "We will be freemen, or we will die...Let us break off all trade and commerce with a people who would enslave us, as the only means to prevent our ruin." 54

Since slavery was ubiquitous in Newport, the juxtaposition of liberty and slavery was a rhetorical device that held a powerful resonance with the town's population. In fact, William Read, the man who donated the Liberty Tree, held 4 slaves on the eve of the Revolution. Every other Son of Liberty who was now in trust of the Liberty Tree (including Ellery, the signer of the Declaration of Independence) held two to four slaves, except for John Collins, who had $13 .{ }^{55}$ The Sons of Liberty who feared British enslavement were the same prominent Newporters who held the most slaves. But the Sons never acknowledged this contradiction. When a copper plate that commemorated the repeal of the Stamp Act was stolen from the base of the Liberty Tree in 1767, an angry contributor to the Newport Mercury took the occasion to remind Newport's citizens of the connection between liberty and slavery. The author first contended that "Monuments of Liberty, with their Inscriptions, have always been held sacred, in all Ages of the World, in all free Governments." He then questioned who "would stoop to so sordid, so ignoble, 
so infamous an Action" as stealing this sacred plate during a time of Revolutionary crisis.

Finally, the discourse suggested that the offender was much more than an enemy to the spirit of liberty. "Such men," the article proclaimed, "ought to meet with universal Discountenance...He who would enslave us, I repeat it, is an Enemy to the human Species; and he who dares to destroy the Monuments of public Liberty, would enslave us if it was in his Power." ${ }^{56}$ Rarely has this juxtaposition of slavery and freedom seemed so obvious than in the conversion of Newport's Liberty Tree from a ceremonial site used by African slaves to a sacred space appropriated by the Sons of Liberty in their struggle against their own enslavement.

\section{Conclusion}

The Sons of Liberty certainly appropriated a traditionally African space for their own battle against tyranny and enslavement, but the question of whether Newport's Liberty Tree was a contested space is debatable. Indeed, if Africans and Anglo-Americans fought over this space, then it might certainly be described as what Mary Louis Pratt has called a "contact zone": a space "where cultures meet, clash, and grapple with each other, often in contexts of highly asymmetrical relations of power." ${ }^{, 57}$ Perhaps there were fights at the tree. Perhaps the person who stole the plaque from base of the tree was an African slave offering a physical and symbolic gesture of resistance to American slavery. Yet this is mere conjecture. Indeed, from 1766 to the beginning of the Revolution, it appears the tree was used by both groups at different times, for different reasons, during the year. The tree thus became converted and reconverted every year in March and June.

If the African and Anglo-American communities shared used the Liberty Tree for their own ceremonies at different times of the year, they both also felt the deleterious effects of war coming home to Newport. As the town, and the colonies, plunged into a Revolutionary war, all 
evidence of either the annual black elections or Liberty Day celebrations completely disappeared. The symbol of the tree, however, survived. In his extraordinarily influential Common Sense, Thomas Paine employed the metaphor of a maturing sapling to highlight the propitious timing of the Revolutionary movement. He also suggested that governments would hold council under large trees and turn to them for inspiration, guidance, and wisdom. ${ }^{58}$ Paine even composed an amorous poem entitled "Liberty Tree," which he published in the Pennsylvania Magazine in 1775. The final verses of the poem read:

But hear, O ye swains, 'tis a tale most profane, How all the tyrannical powers, Kings, Commons and Lords, are uniting amain, To cut down this guardian of ours; From the east to the west blow the trumpet to arms, Through the land let the sound of it flee, Let the far and the near, all unite with a cheer, In defence of our Liberty Tree. ${ }^{59}$

If the British were trying to cut down American liberty, they also felled Liberty Trees and Poles during their occupation of American seacoast communities. This happened repeatedly in Boston, Newport, and New York. General Gage unceremoniously cut down Newport's Liberty Tree, along with nearly all of the area's other trees, sometime during the cold winters of 17761779. The space stood treeless until a few local residents stole a young sapling from a neighboring farm and planted it where the original buttonwood stood. This new tree would later become a site to celebrate the presidential elections of the early Republic. Gage also sawed down the Liberty Tree in Charleston, South Carolina immediately upon his occupation of that Southern city in $1780 .{ }^{60}$ But just as the concept of a sacred tree had crossed the Atlantic from West Africa and England, the symbol once again re-crossed the Atlantic in the 1780's and 1790's, taking root in Revolutionary France, the Caribbean, and even North Africa as an icon of democracy, fraternity, and equality. Even into the 1820's and 1830's, Andrew Jackson's 
followers rallied around "Hickory Poles" while Henry Clay's supporters demonstrated their devotion with "Ash Poles" (Clay was from Ashland, Kentucky). ${ }^{61}$ The symbol of the sacred tree crossed and re-crossed the Atlantic world during the course of its strange career. Though it took on different meanings in different cultural contexts, the tree maintained its fundamental essence as a sacrosanct symbol and as a culturally meaningful space where communities would gather to embrace their heritage or protest against their enslavement and oppression.

It might seem unusual, even arcane, that Africans and patriotic Americans endowed a tree with such symbolic significance during the Revolutionary era. Yet trees, like mosques, churches, public squares, and other spaces, also function as sites of intense religious, political, and cultural contestation. Though trees are a part of the natural landscape, the meaning ascribed to them is culturally and historically constructed. George Washington's cherry tree certainly differs in cultural meaning from the trees upon which black southerners hanged during the era of Jim Crow. Even the more recent and passionate debate over the use of Christmas or Holiday trees in public spaces highlights the symbolic importance of trees. Both Africans and AngloAmericans gave certain trees sacred status by virtue of their association with creation, life, regeneration, judgment, communal solidarity, and liberty. Newport's black population may have been influenced by white political culture, but the Sons of Liberty themselves became creatures of mimic and imitation when they appropriated a traditionally African ceremonial space as their own. 


\section{Endnotes}

Parts of this paper were first presented to the Draper Graduate Conference on Early American History at the University of Connecticut in September of 2006. I would like to thank Seth Rockman, Karen Halttunen, Robert Gross, and all the participants of that conference, as well as Alan Kraut, Michele Reid, and the two anonymous readers for the Radical History Review, for their insightful comments and suggestions. I would also like to thank Eliga H. Gould, W. Jeffrey Bolster, and especially Bert Lippincott III of the Newport Historical Society for their constant encouragement and assistance.

${ }^{1}$ For the Stamp Act crisis and riots, see Edmund S. Morgan and Helen M. Morgan, The Stamp Act Crisis: Prologue to Revolution (Chapel Hill: University of North Carolina, 1953), Pauline Maier, From Resistance to Revolution: Colonial Radicals and the Development of American Opposition to Britain, 1765-1776 (New York: Vintage Books, 1972), 51-112, Peter David Garner Thomas, British Politics and the Stamp Act Crisis: The First Phase of the American Revolution, 1763-1767 (Oxford: Clarendon Press, 1975), and Edmund S. Morgan, ed., Prologue to Revolution: Sources and Documents on the Stamp Act Crisis, 1764-1766 (Chapel Hill: The University of North Carolina Press, 1959). For the Sons of Liberty and the iconography of patriotic resistance, see Richard Walsh, Charleston's Sons of Liberty: A Study of the Artisans, 1763-1789 (Columbia: University of South Carolina Press, 1959) and Catherine L. Albanese, Sons of the Fathers: The Civil Religion of the American Revolution (Philadelphia: Temple University Press, 1976), Alfred F. Young, Liberty Tree: Ordinary People and the American Revolution (New York: New York University Press, 2006), and David Hacket Fischer, Liberty and Freedom: A Visual History of America's Founding Ideas (New York: Oxford University Press, 2004).

2 "Buttonwood" is a common name for an American Sycamore, which is related to but is not the same as the great California Sycamore. These trees could grow 30 to 40 meters high in their lifetime.

${ }^{3}$ Deed of the Liberty Tree from William Read to William Ellery, John Collins, Robert Crook, and Samuel Fowler, April 14, 1766, Manuscript Collections of the The Newport Historical Society. According to Bertram Lippincott, the Society's archivist, the original copy of this deed is missing. Numerous transcriptions, however, appear in Newport Mercury, April 14-April 21, 1766, Newport Mercury, March 2, 9, and 16 of 1918, Terry, "The History of the Liberty Tree," 8-11, and Louise C. Sherman, "The Liberty Tree" The Green Light, Bulletin of the Point Association, Newport, R.I. Vol. IX No. 3, 4-6.

${ }^{4}$ For the growing colonial belief that British taxation policies were part of a wider conspiracy, see Bernard Bailyn,

${ }^{5}$ For theoretical discussions of the importance of space and place, see commentary by Karen Halttunen, Lawrence Buell, and Philip Deloria in the March 2006 issue of the American Quarterly. Also see Don Mitchell, Cultural Geography: A Critical Introduction (Oxford: Blackwell Publishers, 2000), Gaston Bachelard, The Poetics of Space (New York: Orion Press, 1964), Yi-fu Tuan, Space and Place: The Perspective of Experience (Minneapolis: University of Minnesota Press, 1977).

${ }^{6}$ Henry Bull, "Memoir of Rhode Island," Rhode Island Republican April 19, 1837.

${ }^{7}$ Here I am alluding to one of the two epigraphs with which I began this paper. The other one, from George C. Channing, can be found in George G. Channing, Early Recollections of Newport, R.I., From the Year 1793 to 1811 (Boston: Nichols and Noyes, 1868), 268-270.

${ }^{8}$ See Jay Coughtry, The Notorious Triangle: Rhode Island and the African Slave Trade, 1700-1807 (Philadelphia: Temple University Press, 1981) and Robert K. Fitts, Inventing New England's Slave Paradise: Master/Slave Relations in Eighteenth-Century Narragansett, Rhode Island (New York: Garland Publishers, 1998).

${ }^{9}$ Account of the people in the colony of Rhode-Island, whites and blacks, together with the quantity of arms and ammunition, in the hands of private persons. Compiled by Stephen Hopkins in 1755, reprinted in 1800. See also Lynn Withey, Urban Growth in Colonial Rhode Island: Newport and Providence in the Eighteenth Century (Albany: State University of New York Press, 1984), Elaine Forman Crane, A Dependent People: Newport, Rhode Island, in the Revolutionary Era (New York: Fordham University Press, 1985), 76-83. For some important examples of early American urban history, see Clare Lyons, Sex Among the Rabble: An Intimate History of Gender and Power in the Age of Revolution, Philadelphia, 1730-1830 (Chapel Hill: University of North Carolina Press, 2006), Shane White, Somewhat More Independent: The End of Slavery in New York City, 1770-1810 (Athens: University of Georgia Press, 1991), Simon Middleton, From Privileges to Rights: Work and Politics in Colonial New York City (Philadelphia: University of Pennsylvania Press, 2006).

${ }^{10}$ Richard C. Youngken, African Americans in Newport: An Introduction to African Americans in Newport, Rhode Island, 1700-1945 (Providence: Rhode Island Black Heritage Society, 1998), 5-10. 
${ }^{11}$ See Alden Gamaliel Beamen, Rhode Island Vital Records, New Series Vol. 11 Births 1590-1930 From Newport Common Burial Ground Inscriptions (East Princeton, MA: Rhode Island Families Association, 1985) and http://www.colonialcemetery.com, a website run by Keith Stokes, Director of Newport's Chamber of Commerce. For more on the historical archaeology of the cemetery, see James C. Garman, "Viewing the Color Line Through the Material Culture of Death," Historical Archaeology Vol. 28, No. 3 (1994), 74-93.

${ }^{12}$ Islam had also penetrated into West Africa well before the time of European contact, but there is so far little evidence of Islamic practice in colonial Newport. Furthermore, the debate about whether to describe traditional African religions as animistic, pantheistic, or monotheistic is still highly charged.

${ }^{13}$ Evan M. Zuesse, Ritual Cosmos: The Sanctification of Life in African Religions (Athens: Ohio University Press, 1979), 21. For trees in Lega (a Central African society) culture, see Daniel Biebuyck, Lega Culture: Art, Initiation, and Moral Philosophy Among a Central African People (Berkeley: University of California Press, 1973). For Ge, Arawak, and Caribe creation myths involving a tree, see Claude Lévi-Strauss, The Raw and the Cooked Translated from the French by John and Doreen Weightman (Chicago: The University of Chicago, 1969), 184-186.

${ }^{14}$ James George Frazer, The Magic Art and the Evolution of Kings, Vol. II of The Golden Bough (New York: The Macmillan Company, 1935), 51-52 and Mircea Eliade, Traité D'Histoire Des Religions (Paris: Payot, 1970), 261262. For an analysis of the motif of the tree in Toni Morrison's Beloved, see Michele Bonnet, "'To Take the Sin Out of Slicing Trees...": The Law of the Tree in Beloved," African American Review, Vol. 31, No. 1 (Spring, 1997), 4154.

${ }^{15}$ John S. Mbiti, Concepts of God in Africa (New York: Praeger, 1970), 109-113; Frazer, The Magic Art, 32.

${ }^{16}$ Zuesse, Ritual Cosmos, 153.

${ }^{17}$ Frazer, The Magic Art, 14-15; Mbiti, Concepts of God in Africa, 239-243; Geoffrey Parrinder, African Traditional Religion (Westport, CT: Greenwood Press, 1962), 52-53.

${ }^{18}$ James Albert Ukawsaw Gronniosaw, A narrative of the most remarkable particulars in the life of James Albert Ukawsaw Gronniosaw, an African prince, written by himself (Newport, R.I., 1774), 8-9.

${ }^{19}$ Trees are even a central motif in Toni Morrison's classic African American tale, Beloved. See Bonnet, "“To Take the Sin Out of Slicing Trees," 41-54. For the classic debate over whether Africans were stripped of their culture or whether they experienced a cultural survival, see E. Franklin Frazier, The Negro Family in the United States (Chicago: University of Chicago Press, 1939) and Melville J. Herskovits, The Myth of the Negro Past (New York: London, Harper, and Brothers, 1941).

${ }^{20}$ For the scattered distribution of urban slaves, see the 1774 census: John Russell Bartlett, Census of the inhabitants of the Colony of Rhode Island and Providence Plantations (Providence: Knowles, Anthony, 1858).

${ }^{21}$ Deed of the Liberty Tree.

${ }^{22}$ Bull, "Memoir of Rhode Island." For Newport's black funerary rituals, see John Wood Sweet, Bodies Politic: Negotiating Race in the American North, 1730-1830 (Baltimore: Johns Hopkins University Press, 2003), 332-335.

${ }^{23}$ Black elections were called a variety of names, including Negro 'Lection Day, Coronation Day, and other monikers. For general descriptions of New England's black elections, see Shane White, “'It Was a Proud Day': African Americans, Festivals, and Parades in the North, 1741-1834," The Journal of American History 1 (June 1994), 13-50, William D. Piersen, Black Yankees: The Development of an Afro-American Subculture in EighteenthCentury New England. (Amherst: University of Massachusetts Press, 1988), 117-140, Melvin Wade, "'Shining in Borrowed Plumage': Affirmation of Community in the Black Coronation Festivals of New England, ca. 17501850," in Robert St. George, ed., Material Life in America, 1600-1860. (Boston: Northeastern University Press, 1988), 171-182, Hubert S. Aimes, "African Institutions in America," Journal of American Folklore 18 (Jan-Mar. 1905), 15-32, Joseph P. Reidy, “"Negro Election Day' and Black Community Life in New England, 1750-1860," Marxist Perspectives 1 (Fall 1978), 102-117, Orville H. Platt, "Negro Governors," New Haven Colony Historical Society Papers 6 (1900), 315-335, Alice Morse Earle, In Old Narragansett: Romances and Realities (New York: C. Scribner's Sons, 1898), 80-84, Lorenzo Johnston Greene, The Negro in Colonial New England 1620-1776. (Port Washington, New York: Kennikat Press, Inc., 1942), 248-256, and Joanne Pope Melish, Disowning Slavery: Gradual Emancipation and "Race" in New England, 1780-1860. (Ithaca: Cornell University Press, 1998), 44-47. ${ }^{24}$ For more on African American gatherings and the construction of political identities, see White, "'It Was a Proud Day,' 13-50.

${ }^{25}$ Bull, "Memoir of Rhode Island."

${ }^{26}$ Ibid.

${ }^{27}$ Piersen, Black Yankees, 127-129.

${ }^{28}$ Reidy, "Negro Election Day," 108-109. 
${ }^{29}$ Wade, "Shining in Borrowed Plumage,"174-176. I would also like to thank Catherine Molineux for her suggestions for further reading on the Odwira ceremony.

${ }^{30}$ For a frequently used description of the black elections in other Rhode Island counties, see William J. Brown, The Life of William J. Brown, of Providence, R.I.: With Personal Recollections of Incidents in Rhode Island. (Freeport, New York: Books for Libraries Press, 1971), 10-30.

${ }^{31}$ George Champlin Mason, Reminiscences of Newport (Newport: Hammett, 1884), 76.

${ }^{32}$ Frazer, The Magic Art, 10.

33 J. David Harden, "Liberty Caps and Liberty Trees," Past and Present, No. 146 (Feb., 1995), 74.

${ }^{34}$ William Borlase, The natural history of Cornwall. The air, climate, waters, rivers, lakes, sea and tides; of the stones, semimetals, ... and the manner of mining; ... of the inhabitants. (Oxford: W. Jackson, 1758), 294.

${ }^{35}$ For more on the symbolic significance of wood and trees in European consciousness, their origins in the cyclical nature of the seasons see Simon Schama, Landscape and Memory (New York: Alfred A Knopf, 1995), 23-242. For a discussion of the phallic interpretation of the origins of Liberty Trees, see Schama, Landscape and Memory, 252254. I am particularly indebted to James Roberts for this reference.

${ }^{36}$ Arthur M. Schlesinger, "Liberty Tree: A Genealogy," The New England Quarterly, Vol. 25, No. 4 (Dec., 1952), 435-437. Apparently, Penn's tree was knocked down by a storm in 1810 and was thereafter cut up into relics and sent to various historical societies and governmental officials. I would like to especially thank Thomas Doughton for this reference.

${ }^{37}$ Roderick Terry, "The History of the Liberty Tree of Newport, Rhode Island," Bulletin of the Newport Historical Society No. 27 (October, 1918), 4.

38 Jay Coughtry, The Notorious Triangle: Rhode Island and the African Slave Trade, 1700-1807 (Philadelphia: Temple University Press, 1981), 151 and 252. I would like to especially thank Seth Rockman for this reference to the Sally uprising. The Sally had a long and troubled passage. Owned by Nicholas Brown of Providence and captained by Hopkins, the Sally left Rhode Island in September of 1764 with a crew of 11 men. Hopkins traded for slaves on the African coast in the winter and headed towards Antigua a few months later. On August 28, 1765, there was a massive slave insurrection. Between the slave insurrection, disease, malnutrition, and suicide, the ship lost 106 of its 196 African slaves by the time it reached Antigua. Brown University is supporting an initiative to make the Sally account book, and other documents relating to the slave trade, online. See http://dl.lib.brown.edu/slaveryandjustice/. For the commoditization of nature, see William Cronon, Changes in the Land: Indians, Colonists, and the Ecology of New England (New York: Hill and Wang, 1983).

${ }^{39}$ Silas Downer, A Discourse Delivered in Providence, in the Colony of Rhode-Island, upon the $25^{\text {th. }}$ Day of July, 1769. At the Dedication of the Tree of Liberty, From the Summer House in the Tree. By a Son of Liberty.

(Providence, 1768), 15.

${ }^{40}$ For similar arguments on the unique nature of the American climate and its connection with liberty and progress, see Thomas Jefferson's Notes on the State of Virginia (Philadelphia: Prichard and Hall, 1788).

${ }^{41}$ Albanese, Sons of the Fathers, 47.

${ }^{42}$ Boston Gazette, August 19, 1765. For contemporary descriptions of the events, see the Boston Gazette from August to December of 1765 and see the Providence Gazette, which printed a supplement called Extraordinary on August 24, 1765 (it was out of print from May 11, 1765 until August 9, 1766, apparently for financial reasons). See also Morgan and Morgan, The Stamp Act Crisis, 140-150, Schlesinger, "Liberty Tree," 435-458, and Albanese, Sons of the Fathers, 46-80.

${ }^{43}$ James Thacher, History of the town of Plymouth, from its first settlement in 1620, to the present time: with a concise history of the aborigines of New England, and their wars with the English, \&c. (Boston: Marsh, Capen and Lyon, 1835), 198-199. For Liberty Trees in other communities, see Schlesinger, "Liberty Tree," 435-458, Terry, "The History of the Liberty Tree," and Peter Shaw, American Patriots and the Rituals of Revolution (Cambridge, Mass: Harvard University Press, 1981), 180-184.

${ }^{44}$ Newport Mercury, April 7- April 14.

${ }^{45}$ For more on the Stamp Act Riots in Newport, see Elaine Forman Crane, A Dependent People: Newport, Rhode Island in the Revolutionary Era (New York: Fordham, 1985), 111-129, Sheila Skemp, "Newport's Stamp Act Rioters: Another Look" Rhode Island History, Vol. 47, No. 2 (May, 1989), 41-59, David S. Lovejoy, Rhode Island Politics and the American Revolution, 1760-1776 (Providence: Brown University, 1958), 101-113, Daniel Snydacker, Jr., "The Remarkable Career of Martin Howard, Esq,” Newport History Vol. 61, Part 1 No. 208 (Winter, 1988), 2-16, Allen Mansfield Thomas, "Circumstances not Principles": Elite Control of the Newport Stamp Act Riots," Newport History Vol. 67, Part 3 No. 232 (Winter 1996), 128-143, and Ruth Kennedy Myers and Bradford A. Becken, "Who Was John Webber?" Newport History Vol. 70, Part 2 No. 243 (2000), 34-54. For primary accounts 
of this riot and its aftermath, see the letter from Newport to the Providence Sons of Liberty, dated April 4, 1766 at the Rhode Island Historical Society MSS XII, f. 67 Providence and Henry Marchant, "Report on Losses to Moffatt, Thomas, December 19, 1772," Marchant Papers, Correspondence and Documents, 1772-1784, Rhode Island Historical Society MSS 552.

${ }^{46}$ Dr. Thomas Moffat to Joseph Harrison, Oct. 16, 1765, Chalmers Papers, New York Public Library, cited in Morgan, Prologue to Revolution, William Almy to Elisha Story, Aug. 29, 1765, in Proceedings of the Massachusetts Historical Society Vol. 55 (October, 1921-June 1922), 236.

${ }^{47}$ Newport Mercury May 12-May 19, 1766. There was also a Liberty Pole erected somewhere near the "Point" section of Newport, but it was not revered as much as the Tree and it was used mainly as a point of reference. See classified ads in the Newport Mercury, January 2, 1769 and March 19, 1770. See also Terry, "The History of the Liberty Tree," 16.

${ }^{48}$ Franklin Dexter Bowditch, January 1, 1769-March 13, 1776, vol. 1 of The Literary Diary of Ezra Stiles (New York: Charles Scribner's Sons, 1901), 527. For the annual Liberty Day celebrations in Newport, see the March $18^{\text {th }}$ entries in this diary from 1769 to 1775 .

${ }^{49}$ Abbe Henri Gregoire, Essai Historique et patriotique sur les arbres de la liberte (Paris, an II [1793-1794]). Quoted in Harden, "Liberty Caps and Liberty Trees," 88. Harden suggested that one use the facsimile reprint in Oeuvres de l'abbe gregoire, 14 volumes, (Nendeln, 1977), xii, pages 26-27.

${ }^{50}$ Franklin Dexter Bowditch, ed., Extracts from the itineraries and other miscellanies of Ezra Stiles, D.D., LL. D., 1755-1794 (New Haven: Yale University Press, 1916), 513 and Shaw, American Patriots and the Rituals of Revolution, 184.

${ }^{51}$ Deed of the Liberty Tree.

${ }^{52}$ See Edmund S. Morgan, American Slavery, American Freedom: The Ordeal of Colonial Virginia (New York: W. W. Norton, 1975) and David Brion Davis, The Problem of Slavery in the Era of Revolution (Ithaca: Cornell University Press, 1975).

${ }^{53}$ Charles Warren, Jacobin and Junto, or, Early American Politics as Viewed in the Diary of Dr. Nathaniel Ames, 1758-1822 (New York: Benjamin Blom, 1968), 33-34.

${ }^{54}$ Silas Downer, A Discourse Delivered in Providence, 15.

${ }_{55}^{55}$ Bartlett, Census of the inhabitants of the Colony of Rhode Island, This is a later copy of the 1774 census.

${ }^{56}$ Newport Mercury, August 24 - August 31, 1767.

${ }^{57}$ Mary Louise Pratt, "Arts of the Contact Zone," in David Bartholomae and Anthony Petrosky, eds., Ways of Reading: An Anthology for Writers, $5^{\text {th }}$ ed. (Boston: Bedford St. Martin's, 1999), 584. For more on contact zones and their relevance for colonial writing, see Pratt, "Arts of the Contact Zone," Profession 91 (1991) and the introduction to Pratt, Imperial Eyes: Travel Writing and Transculturation (London: Routledge, 1992).

${ }^{58}$ Thomas Paine, Common sense: addressed to the inhabitants of America, on the following interesting subjects. I. Of the origin and design of government in general, with concise remarks on the English Constitution. II. Of monarchy and hereditary succession. III. Thoughts on the present state of American affairs. IV. Of the present ability of America, with some miscellaneous reflections. Written by an Englishman. (Philadelphia: R. Bell, 1776), 2 and 17. I would like to thank Robert Gross for this reference.

${ }^{59}$ Pennsylvania Magazine; or American Monthly Museum, July, 1775.

${ }^{60}$ Schlesinger, "Liberty Tree," 441-442 and Terry, "The History of the Liberty Tree," 17-18.

${ }^{61}$ For Liberty Trees and the French Revolution see Harden, "Liberty Caps and Liberty Trees," 66-102 and Mona Ozouf, Festival and the French Revolution, translated by Alan Sheridan (Cambridge, Mass: Harvard University Press, 1988), 230-260. For Caribbean revolutions, see Laurent DuBois, Avengers of the New World: The Story of the Haitian Revolution (Cambridge, Massachusetts: Harvard University Press, 2004) and DuBois, A Colony of Citizens: Revolution and Slave Emancipation in the French Caribbean, 1787-1804 (Chapel Hill: University of North Carolina Press, 2004). For Liberty trees in North Africa in the late $18^{\text {th }}$ Century, see Schama, Landscape and Memory, 252-254 and Joel Barlow, Genealogy of the Liberty Tree, Barlow Papers, Houghton Library, Harvard University. For presidential celebrations at the new Liberty Tree in Newport, see Channing, Early Recollections of Newport, R.I.,268-270. 